\title{
Frustrated by regulatory delays at FDA, biotech companies warm to user fees
}

\begin{abstract}
Washington. The US biotechnology industry has reversed its policy and now accepts user fees as the best way to win rapid approval of new products by the US Food and Drug Administration (FDA). At a congressional hearing last week, industry representatives testified in support of FDA's plans to levy fees so that it could hire some 600 scientists and hasten the review of new drug applications. Although industry dislikes the concept, many companies have come to believe that industry subsidies are the only way to speed the process at a time when major funding increases for FDA are unlikely.
\end{abstract}

David Kessler, the FDA commissioner, testified last week that user fees could provide a financial lift to an agency faced with an expanding work load, particularly in biotechnology. A bill containing the provision is expected to be introduced next month in the House of Representatives by Henry Waxman (Democrat, California) and John Dingell (Democrat, Michigan).

This belated endorsement of user fees by industry is "recognition of the gravity of the situation and the necessity for action", says Richard Godown, president of the Industrial Biotechnology Association (IBA). He points out that it is the first time there has been agreement between the legislative branch, the regulatory branch and the industry on the issue. As recently as January, when President George Bush presented Congress with his budget request for fiscal year 1993, IBA opposed the administration's proposal for user fees out of fear that it would increase the already high costs of drug development and hinder product research and development. Industry executives have argued that user fees would be particularly burdensome to the smaller biotechnology companies with little or no sales revenues.

At a press meeting last month, Kessler said that the levying of user fees had become "absolutely critical". Without them, he said, "this agency is not going to be able to survive". Agency officials were forced to institute a hiring freeze in July after it became clear that FDA would receive little more than a cost-of-living increase for next year. Last week, Congress confirmed FDA's fears and gave the agency $\$ 746$ million, only 2.8 per cent more than this year's budget.

Kessler says that he would use the money raised through user fees to hire an additional 300 inspectors for the Center for Drug Evaluation Research (CDER) and another $\mathbf{3 0 0}$ for the Center for Biologics Evaluation Research (CBER). In return, Kessler says that FDA would aim to shorten to six months the average review time for priority drug applications, that is, drugs for lifethreatening diseases or diseases for which there are no alternative therapies. Review times for other standard drug applications would be reduced by half from an average of two years to one year, according to the FDA.

FDA hopes to be able to raise $\$ 35$ million in user fees in the first year, $\$ 50$ million in the second and $\$ 75$ million in the third and each year thereafter. Companies would typically make a one-time payment of about $\$ 150,000$ for drug applications and pay smaller annual fees for products that are on the market and for manufacturing plants. Smaller companies may be charged lower fees for some services. Initially, neither medical devices nor generic drugs would be included in the plan.

While the three trade associations IBA, the Association of Biotechnology Companies and the Pharmaceutical Manufacturers Association - have agreed in principle to the concept of user fees, many details are not yet resolved. Industry would like to see the fees used to improve the speed and quality of the review of new product applications (that is, new drug applications and product licence applications) carried out by CDER and CBER rather than for such FDA activities as enforcement. In addition, the industry wants the FDA to accept 'performance standards' that, if not reached, would allow Congress to refuse to reauthorize its programmes.

Larry Kurtz, vice-president of corporate communications for Chiron Corporation in California, says his company supports the concept of user fees so long as they are "an increment to the FDA budget and not simply a substitute for reduced federal spending".

Waxman and Dingell will be hardpressed to get the bill passed in the few months that remain in this current legislative session. But the bill is expected to move quickly next spring once it is brought before a new Congress.

Diane Gershon

\section{Scientists deny alleged support of company's 'new nuclear science'}

Washington. Ten scientists cited as supporters of a nuclear theory that is the foundation of a new cold fusion company are complaining that they do not in fact support the theory and that their names have been used without their knowledge.

A little-known physicist-entrepreneur, Ronald Brightsen, claims to have pioneered a new nuclear science based on his 'nucleon cluster model' of the atomic nucleus. In a press release dated 10 August, Brightsen asserts that the model will "provide a clear path" to "cold fusion power", and lists 16 'Supporters of the Nucleon Cluster Model', many of them scientists. But the ten who could be reached last week deny supporting Brightsen's model and object to the use of their names.

Brightsen's new physics rests on the premise that the atomic nucleus consists of discrete 'clusters', each containing a different number of neutrons and protons. He has predicted that cold fusion home heaters based on this theory could be on the market within three to ten years. Brightsen, who earned a master's degree in nuclear chemistry from the Massachusetts Institute of Technology (MIT) in 1950, claims his findings have been "praised by leading experts" on nuclear energy.

But many physicists, including some of Brightsen's alleged supporters, have dis- missed his model. "When I [last] saw it several years ago, it was more numerology than anything else", says Warren Buck, a professor of physics at Hampton (Virginia) University who is listed as a supporter.

Buck, like many of the other scientists listed in the press release, says that he reviewed the cluster model during the 1980 s at Brightsen's request and found it interesting but unconvincing. Besides Buck, ten other 'supporters' have repudiated the model. (Of the remaining five, two could not be contacted and two - including retired Admiral Elmo Zumwalt, the former chief of US naval operations - are non-scientists.)

To develop cold fusion and other technologies based on his findings, Brightsen and others have founded Clustron Sciences Corporation (CSC) in Reston, Virginia. CSC's vice president of research is Eugene Mallove, a former MIT science writer who accused researchers at the MIT Plasma Fusion Center of misconduct for suppressing possible evidence of cold fusion (see Nature 353, 98, 1991).

"Perhaps 'supporters' was a bad choice" of words, Brightsen admits. But he says "we think what's in the press release is accurate, subject to interpretation."

Tracl Watson 